University of Texas Rio Grande Valley

ScholarWorks @ UTRGV

$1-2020$

\title{
CHAPTER 11 Lydia Mendoza, "Reina de la Música Tejana”: Self- Stylizing Mexicanidad through China Poblana in the US-Mexico Borderlands
}

Marci R. McMahon

The University of Texas Rio Grande Valley, marci.mcmahon@utrgv.edu

Follow this and additional works at: https://scholarworks.utrgv.edu/lcs_fac

Part of the Latin American Languages and Societies Commons, and the Modern Literature Commons

\section{Recommended Citation}

McMahon, Marci R.. "CHAPTER 11 Lydia Mendoza, "Reina de la Música Tejana”: Self-Stylizing Mexicanidad through China Poblana in the US-Mexico Borderlands". meXicana Fashions: Politics, SelfAdornment, and Identity Construction, edited by Aída Hurtado and Norma E. Cantú, New York, USA: University of Texas Press, 2021, pp. 237-261. https://doi.org/10.7560/319581-012

This Book is brought to you for free and open access by the College of Liberal Arts at ScholarWorks @ UTRGV. It has been accepted for inclusion in Literatures and Cultural Studies Faculty Publications and Presentations by an authorized administrator of ScholarWorks @ UTRGV. For more information, please contact justin.white@utrgv.edu, william.flores01@utrgv.edu. 
$<$ PN $>$ Section III

$<$ PT $>$ The Politics of Entrepreneurship

$<$ PS $>$ Making(It) / Selling It 


\section{$<\mathrm{CN}>$ Chapter 11}

$<\mathrm{CN}>$ Lydia Mendoza, "Reina de la Música Tejana"

$<\mathrm{CS}>$ Self-Stylizing Mexicanidad through China Poblana in the US-Mexico Borderlands

$<$ CA >Marci R. McMahon

$<$ EP $>$ I sew my own costumes for my performance work. I make the flowers, and then I make the dresses, my housedresses, everything. ...

My sisters often tell me, “Ay, Lydia, you have so much spirit. Where do you get the energy to be fixing yourself up, doing your hair, makeup, dressing up, going to the radio station and television stations, and ... well, not me.” They say they couldn't bear to do it anymore. "Well, I can," I tell them. $<$ ES $>$ Lydia Mendoza, qtd. in Broyles-González, Lydia Mendoza’s Life

$<$ TXT>In 1950, Tejana singer Lydia Mendoza was asked by the mayor of Chihuahua City, Mexico, to perform in two concerts for which he would pay her five thousand dollars. At that point in her career, she had already established her popularity among working-class mexicano audiences in the United States and Mexico. She was hailed by fans with the nicknames La Alondra de la Frontera (the Meadowlark of the Border) and La Cancionera de los Pobres (the Singer of the Poor), and later honored as Reina de la Música Tejana (Queen of Tejano Music), titles that would follow Mendoza throughout her long career--from the early 1930s to the late 1980s--as a singer and guitarist performing canciones rancheras and norteño. Mendoza's childhood and performance life indicate a cross-regional and cross-national existence: she was born in Houston, Texas, in 1916; lived in Monterrey, Mexico; and then moved to San Antonio, 
Texas, before she began traveling throughout the United States, Mexico, and Latin America as a performer.

Mendoza first began performing in the late 1920s and early 1930s with her family in San Antonio’s Plaza del Zacate (Haymarket Plaza, now Milam Plaza), singing and playing the mandolin. She then began to sing canciones rancheras and play a twelve-string guitar with her family's musical group, which included her mother, brothers, and sisters. They performed in variedades (variety shows), in carpas (tent shows), and teatros (Spanish-language theatre) throughout the Southwest, including New Mexico and California, entertaining primarily working-class mexicano audiences. She also performed with her family in the Midwest in the 1930s and in New York in the 1940s. While Mendoza was playing in the Mendoza Family Variety Show, from the 1930s to the 1950s, she simultaneously established her popularity and celebrity as a performer of the ranchera genre in her own right; during this time she recorded several solo records, many for major American labels, including RCA Victor.

Acknowledging Mendoza's popularity, the family frequently made her the headline act in their variety show. When she began to perform solo in the 1950s, including at the Chihuahua City show, Mendoza's fame increased among audiences throughout Mexico and Latin America. ${ }^{1}$ From the 1960s to the 1980s, Mendoza propelled herself into the US national spotlight as she toured folklife festivals and universities (Broyles-González, Lydia Mendoza’s Life xi-xv; Strachwitz and Nicolopulos).

The Chihuahua City concert invitation in 1950 was the first time Mendoza was asked to perform solo, and the five thousand dollars she was paid was a considerable amount by the day's standards; it was also the largest sum of money Mendoza had ever been offered to perform her music (Strachwitz and Nicolopulos 274). With this in mind, both Mendoza and her promoter, 
Ramiro Cortés, agreed to do the two-night concerts and headed to Chihuahua in Cortés's car (247). Cortés recalls that when they approached the city, they were met by what he first believed to be immigration officials standing alongside a makeshift tent on the side of the highway (275). When the residents discovered that the much-anticipated Lydia Mendoza was in the car, she and Cortés were greeted by the mayor of Chihuahua, the chief of police, and two other politicians, who told Cortés, "We have a parade going, we have a parade fixed for Lydia, and we want her to get dressed in that little tent—put on her costume, you know, for the parade" (275). As her promoter, Cortés explained to Mendoza what was expected:

$<\mathrm{EX}>[\mathrm{S}]$ o I told Lydia what it was all about, and she got dressed in that little tent. She changed into one of her costumes and everything. Then they put her in an open car, a brand-new Oldsmobile convertible, which was followed by a truck, a big, beautiful truck, all with ribbons and flowers, a full mariachi band and a big arch that says, "Lydia Mendoza" riding on the flatbed. (qtd. in Strachwitz and Nicolopulos 275)

$<\mathrm{TXT}>$ The costume Mendoza changed into was one of the many hand-sewn and sequinembroidered versions of the china poblana dress that had already become an iconic feature of her public performance persona both on and off stage. The china poblana outfit typically consists of an embroidered white blouse, sequined skirt, and petticoat, and a rebozo in the colors of the Mexican flag (green, white, and red). ${ }^{2}$ This type of costume for female singers of canciones rancheras - a genre that emerged in postrevolutionary Mexico and is considered by many to be “an ideal expression of lo mexicano" (Nájera-Ramírez 186)—has functioned generally as a symbol of Mexican nationalist identity and culture. Female ranchera singers such as Mendoza 
who chose to don china poblana costumes in the mostly male-dominated music industry and performance spaces in both the United States and Mexico in the early and mid-twentieth century confronted and negotiated the multiple and contradictory racialized and gendered meanings of this iconic attire. This style of dress (the loose-fitting blouse, colorful rebozo, and sequined skirt) was first worn by Indigenous and mulatto women in the region of Puebla, Mexico. By the late eighteenth century and early nineteenth century, the term china poblana came to designate "a well-dressed mestiza woman" in Mexico (Randall 72). ${ }^{3}$ Due to its fusion of European and Indigenous elements, china poblana attire was appropriated in post-revolutionary Mexico as a nationalist symbol of modern Mexican identity. This identity was defined through mestizaje, which signifies the mixture of Spanish and Indigenous cultures in Mexican nationalist discourse, even though Mexican cultural identity encompasses multiple racial and cultural influences in the Americas, including African, Native American, European, and Asian (Pérez-Torres xi). The term mestizaje was used by nationalists to depict a "teleology of progress" (Pérez-Torres 14), thereby subsuming Indigenous identity and other racialized identities in the Mexican nation into the “more formulaically more progressive mestizo" (Saldaña-Portillo 407). ${ }^{4}$ As a symbol of Mexican modernity from the 1920 s to the 1940 s, the china poblana style was adopted by Mexican intellectuals and elites, and became fashionable attire for celebrities and society ladies (Hershfield 106; Randall 133). While some popular figures, such as the Mexican actress Lupe Vélez, wore china poblana dresses as the latest fashion trend, thereby romanticizing Indigenous cultures, others, such as the painter Frida Kahlo, wore china poblana outfits to demonstrate solidarity with Indigenous women. ${ }^{5}$

By the time of Mendoza's Chihuahua City concerts in 1950, the china poblana costume was everywhere as an image of lo mexicano (or Mexican-ness) in Mexican and US films, 
advertisements, calendars, tourist brochures, and public cultural events. For the Chihuahua City officials and public, the costume was such a signature piece of Lydia Mendoza's performance persona that they expected her to don this outfit for their parade, even setting up the tent for changing into this costume. In a photo of the singer in the parade, Mendoza is propped up on the back seat of the Oldsmobile convertible between two smiling women not wearing the costume (fig. 11.1).

$\{$ FIG 11.01 about here $\}$

Mendoza had on a white embroidered blouse with an image of herself in china poblana sewn on the front (a unique feature), had her hair in ponytails with colorful ribbons, and was wearing long earrings and necklaces. By sporting two ponytails, Mendoza self-stylized the costume. Even though there are variations in the hairdos of women who perform in china poblana outfits, the style constructed by nationalist imagery is two long braids tied with red, green, and white ribbons. But in the many photos of Mendoza throughout the 1940s and 1950s, she wears two side ponytails ("pigtails"), a typical feature of her hairstyle during this period. The 1950s parade photo also shows Mendoza's sequined skirt, which she wore in all performance and publicity photos during this time. The outfit included a petticoat, which she fashioned to the fullest extent toward the end of her career. ${ }^{6}$

In this chapter, I argue that Mendoza's self-stylizations of the china poblana costume, including her exaggerated and unique fashioning of this well-established symbol of Mexican national identity both on and off the stage, provided a spectacle by which to produce mexicanidad on both sides of the border. The concept of lo mexicano, what Laura Gutiérrez 
defines as "all things Mexican," connotes a fixed understanding of Mexican identity and culture, even as the concept cautions against equating Mexican-ness with the commercialization of Mexican culture or as an entertainment novelty (Gutiérrez 21; Vargas, Dissonant Divas 39). Mexicanidad, on the other hand, functions as a malleable concept, and when deployed by artists and performers, as Gutiérrez explains, it becomes a "performance/performative strateg[y] to challenge general and fixed understandings of "lo mexicano"' (21). Significantly, even while deploying mexicanidad, artists do not "completely distance themselves from this dominant narrative of national and cultural belonging" (Gutiérrez 21). With this understanding of mexicanidad, I suggest that Mendoza's self-stylizations of the costumes were consumed as a pleasurable spectacle by transnational mexicano audiences that embraced the china poblana as a symbol of Mexican identity and culture, even as the iconic attire risked corresponding with the commercialization and exoticization of the outfit as a stereotypical symbol of Mexican culture and identity. ${ }^{7}$ As Deborah Vargas point out, Rosita Fernández, a contemporary of Mendoza who also wore the china poblana costume as part of her performance persona, it is crucial to situate "how, where, by whom, and for whom 'lo mexicano' is produced and how it is engaged" (Dissonant Divas 39).

The ranchera musical genre and mexicano performance venues, including las carpas and los teatros, were critical spaces in which Mendoza began to perform china poblana as a symbol of mexicanidad. Mendoza's choice of the china poblana did not come from an outsider, such as a promoter directing her what to wear; rather she donned and self-stylized the dress from a confluence of factors derived from her personal history and the transnational mexicano audiences to which she performed. Significantly, Mendoza's mother, Leonor, first began to hand-sew the costumes for the family's variety act in the early 1930s (Broyles-González, Lydia Mendoza's 
Life 50; Strachwitz and Nicolopulos 120). In addition to the china poblana outfits for her daughters, the mother sewed accompanying charro attire for her sons, an outfit characterized by tight, ornamented pants, boots, a broad hat, and an equestrian jacket (Broyles-González, Lydia Mendoza's Life 50). ${ }^{8}$ Leonor sewed the costumes herself because the family could not initially afford to buy them, and they were unavailable in San Antonio. Mendoza recalled,

$<\mathrm{EX}>$ We had no money; there were no means which to go to Laredo and buy a charro outfit. Well, my mother used her imagination. She went and bought black pants and stitched them on the inside in order to taper them like a charro outfit. Then she sewed a zipper on the side seams. ... She went and bought a few dozen very pretty buttons that looked just like silver, just like on those charro pants.... Same thing for my sister Juanita: she fixed up her Mexican dress. . . After time passed and we began to make some money, we did go to Monterrey and she bought my brother his real charro outfit. (qtd. in Broyles-González, Lydia Mendoza’s Life 50)

$<$ TXT $>\quad$ Mendoza's brother said that when their mother first began to sew these costumes, she envisioned "herself as wearing a typical Mexican costume, one of those fancy ones like the famous Mexican ranchera singers wear" (qtd. in Strachwitz and Nicolopulos 120). Fully aware that the china poblana and male charro figures were already staples of Mexican popular media, the mother made a savvy choice to create the costumes for their performances in las carpas and los teatros, entertainment spaces influenced by Mexican popular culture. Following her mother's example, Mendoza continued to hand-sew her china poblana costumes even after she became popular and had the money to buy them. By sewing her own costumes, Mendoza was able to 
self-stylize the outfits in a variety of ways, and the act of sewing her own dresses, in some respects, contributed to audiences' perception and embrace of Mendoza as a working-class figure. Furthermore, as evidenced by the epigraphs to this chapter, Mendoza derived great pleasure from the artistic endeavor of sewing and designing.

Scholars who have analyzed Mendoza as a musical figure have paid scant attention to her costuming as integral to the cultural, emotional, and spiritual dimensions of her performances for transnational mexicano audiences. Yolanda Broyles-González's scholarship and published oral history of Mendoza have provided scholars with path-breaking work on this legendary figure. She analyzes the roles of Mendoza's music, voice, and aurality in the "formation and sustenance of mexicana/o working-class identity," which she suggests provided a "shared affirmation of a common experience” for Latina/o audiences (Lydia Mendoza's Life xiii). She also centers a crucial gendered history of Mendoza's life and performance career, spotlighting how the women of the Mendoza clan were the backbones of the family, arguing that Mendoza's oral history provides an important “womanist and woman-centered document” (xi). Broyles-González’s oral history with Mendoza and Chris Strachwitz and James Nicolopulos's biography of the iconic singer and her family provide rich, detailed histories of Mendoza's musical and performance career, her encounters with racial discrimination as she and her family sought to play in segregated performance spaces in the US Southwest, and her profound influence on workingclass mexicano audiences who were racialized and deemed "foreigners" within the literal and figurative boundaries of the United States. For Broyles-González, Mendoza's costuming, along with her music, was central to her claiming space and belonging for mexicanos in the United States. She explains, "Her flamboyant performance attire as well as song style and repertoire loudly proclaimed a mexicana politics of place and of belonging for native people officially 
deemed as not belonging to the United States - and targeted for deportation and 'repatriation"' (Lydia Mendoza's Life 188).

This chapter explores Mendoza self-stylizations of the china poblana outfit as a central component of what Nájera-Ramírez refers to as the "dynamics of performance," which for Mendoza included a variety of elements, including her singing style, costuming, gestures, and other theatrical devices (199). With her music and china poblana costuming, Mendoza presented an overall integrated performance that moved audiences on both sides of the border; her artistry as and constructed costuming created a form of unity despite differences in history, language, citizenship, and temporal circumstances. Through her fashioning of the china poblana costume in ways that made it integrated and central to her sonic performances, Mendoza as a performer bridged two nations and two peoples that have deep historical and cultural connections; such transcultural connections became embodied and expressed in Mendoza's attire as part of her performance of mexicanidad throughout her career.

$<\mathrm{A}>$ Performing China Poblana in Canciones Rancheras in las Carpas and los Teatros

$<\mathrm{TXT}>$ Ranchera music, as a transnational musical genre, connects two interconnected geographies and nations of a migratory people with deep historical roots. The canción ranchera first developed and emerged in post-revolutionary Mexico as the nation experienced an increase in urban migration. Within the space of Mexico itself, the genre therefore first expressed a longing for lo mexicano, conceived as a romanticized way of life on the hacienda before the emergence of modernization and industrialization (Peña 11). As Nájera-Ramírez explains, “[E]voking a rural sensibility, the ranchera expressed nostalgia for a provincial lifestyle and 
projected a romanticized idyllic vision of the past" (185). In Mexico, the ranchera became widely popular through comedias rancheras (western musical comedies, both filmed and on the radio). They rose to popularity in the 1930s in Mexico using aspects of comedy, tragedy, popular music, and folklore, and incorporated nationalistic themes and songs typical of the ranchera genre (Hershfield 106; Nájera-Ramírez 186). Joy Elizabeth Hayes explains how the comedias rancheras throughout the 1920s and 1930s "engaged listeners in a unifying national discourse" (245-246). For mexicano migrants in the US Southwest (a population that grew from the 1920s to the 1940s due to the aftermath of the Mexican Revolution, agricultural labor demands, and the implementation of the bracero program, among other structural factors) the ranchera "remember[ed] what displaced peoples are supposed to forget," particularly "the heart-felt longing for a return to the beloved homeland - the return that immigrant populations often yearn for and rarely achieve” (Broyles-González, "Ranchera Music(s)” 357). ${ }^{9}$

The transnational circulation of lo mexicano through ranchera music and the comedias rancheras, and the centrality of this genre as a form of entertainment in las carpas and los teatros in the US Southwest, inspired the Mendoza family to don china poblana and charro costumes in the late 1930s. When Mendoza first began performing at a very young age with her family in Plaza del Zacate (Haymarket Plaza) in San Antonio and other spaces (mostly cantinas and restaurants) throughout Texas and the Midwest during the late 1920s and early 1930s, the family did not wear costumes. As Mendoza explains, "We have never worn costumes when we were singing down there in the Plaza del Zacate. We would just be there singing in whatever clothes we had. But when we started to put on a real show, to do salons, halls and theaters and all that, we realized that we needed costumes" (qtd. in Strachwitz and Nicolopulos 119). Mendoza and her family also did not wear costumes when they performed as El Cuarteto Carta Blanca (the 
Carta Blanca Quartet) in community halls throughout the Rio Grande Valley and elsewhere in Texas during this period. Nor did they wear costumes when they traveled north to Michigan, where they followed the migrant farm work circuit with the intention to perform and earn money entertaining. They traveled to Michigan with contracts to work in the beet fields, but after a week they got a job performing in the only Mexican restaurant in the area (Broyles-González, Lydia Mendoza's Life 6-7).

The china poblana attire became central to Mendoza's performance in the Mendoza Family Variety Show in carpas from approximately 1933 to 1935, and in Spanish-language teatros throughout the US Southwest from about 1935 to 1941 . The family stopped touring in 1941 due to the escalation of World War II (Broyles-González, Lydia Mendoza’s Life 50; Strachwitz and Nicolopulos 120). ${ }^{10}$ The Mendoza Family Variety Act resumed six years later and performed in both teatros and carpas from about 1947 to 1954.

Mendoza's mother developed not only the costumes for their shows but also the routines. Mendoza's brother Manuel and sister Juanita did comedy skits and performed Mexican dances (including the jarabe tapatío, a popular dance that dates back to the colonial era in Jalisco, and which by the 1920 s was associated with both the charro and china poblana). Juanita also performed duets and danced with her sister María, and as the closing act, Mendoza sang and played her guitar. She never performed in the comedy skits (Strachwitz and Nicolopulos 161).

During these decades, las carpas and los teatros were infused with entertainment that deployed images of mexicanidad reflecting the transnational Mexican audiences that frequented these venues. Carpas offered Spanish-language shows and circus-like entertainment, and initially were sites for showing Spanish-language Mexican movies, many of which featured Mexican actresses in china poblana attire (Vargas, "Rita's Pants" 5, and "Rosita Fernández" 170). 
Mendoza described the atmosphere and entertainment of the most well-known carpas in Texas (where she and her family performed)--including Carpa Cubana, Carpa García Mendoza, Carpa Monsivais, and El Teatro Carpa--as including several carnivalesque elements, including trapeze artists, jugglers, dancers, clowns, tightrope walkers, pantomimes, chorus dancers, and comedy skits (Strachwitz and Nicolopulos 77). These tent shows differed from those in teatros or Mexican-operated theaters in San Antonio, including Teatro Nacional, which catered mostly to middle-class mexicano audiences and offered other forms of live entertainment (Vargas, "Rita's Pants" 5). As Vargas explains, in the early decades of the twentieth century, carpas provided alternatives to segregated performance venues such as dance halls and public theaters, which specifically prohibited non-Anglo performers and audiences (Dissonant Divas 23$).{ }^{11}$ As they began to enter los teatros, Mendoza and her family were often the opening, intermediary, or closing act for popular and celebrated Mexican films from the late 1930s, which featured famous Mexican actresses wearing china poblana costumes, as well as English-language Hollywood films. Mendoza described how at the California Theater in Los Angeles in 1939, she and her family performed between the showing of a "very popular Mexican film and another, Englishlanguage movie" (qtd. in Strachwitz and Nicolopulos 143).

A poster announcing the Mendoza Family Variety Act at Teatro Azteca in Calexico, California, on March 3, circa 1940s, illustrates the close associations between the costumes worn by the Mendoza family in their variety act and the clothing worn by Mexican film stars in the ranchera movies. In this performance, Mendoza and her family opened for the Mexican film Bajo el Cielo de México (1937), directed by Fernando de Fuentes, who also directed the comedia ranchera Allá en el Rancho Grande, which established the genre and featured Mexican film actor Esther Fernández wearing china poblana costumes in both the film and publicity stills. ${ }^{12}$ The film 


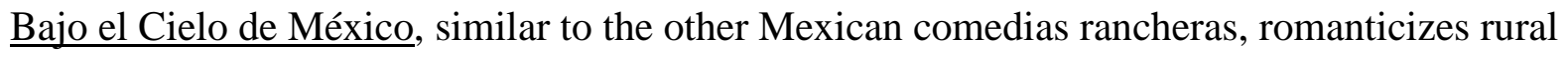
life on the hacienda. The movie focuses on a rancherita named La China (played by the popular Mexican actor María Luisa Zea) who falls in love with the foreman Juan Manuel (played by Argentinean actor Rafael Falcón). Zea, who appeared in many Mexican ranchera films, played another china poblana character in the popular Mexican film La India Bonita (1938). ${ }^{13}$ The china poblana archetype in Mexican films continued throughout the 1940s, with popular Mexican actor María Félix playing one in the popular film La China Poblana (1944), directed by Fernando Palacios. The narrative follows Félix, who plays the character Señora de la Barca, the wife of Spain's first Mexican ambassador, who comes across a china poblana dress that is cursed and known to bring disaster upon anyone who wears it; she chooses to defy superstition by wearing the forbidden gown.

As evidenced by publicity posters of the period, Lydia Mendoza fashioned a modest look in her performances in las carpas and los teatros, rarely donning the off-the-shoulder and low-cut blouses worn by other performers during this period. Even though carpas offered, as Vargas explains, "a financially accessible and 'respectable' performance space for young women, as carpas were often a family venue and young women singers were often chaperoned by elder family or members in the troupe" ("Rita's Pants" 5), women who performed in these public venues confronted sexist views that deemed their presence a violation of hegemonic gender roles. As Nájera-Ramírez suggests, "For women to sing outside of domestic spaces is already a transgression of traditional gender roles, but to sing in adult-oriented sites is especially challenging" (201). Mendoza directly confronted such sexist views when she played in nightclubs and bars later in her career when her first husband publicly, and even at one venue, angrily disapproved of her performances (Nájera-Ramírez 201). With self-costuming, therefore, 
female performers could stylize the china poblana costume to negotiate or mitigate the view of their chasteness and sexuality as suspect. ${ }^{14}$ Mendoza certainly donned modest china poblana costumes early in her career, even if she did not do so consciously, perhaps in response to the dominant cultural view of women as sexually transgressive when they stepped out as performers in public.

$<$ A > Self-Stylizing the China Poblana as a Tejana and Ranchera Singer On and Off the Stage

$<$ TXT > As a Mexican nationalist symbol, ranchera music and the accompanying china poblana costume construct idealized womanhood shaped by heteronormative constructions of the nation (Vargas, "Rita's Pants" 3-4; Nájera-Ramírez 186). As a representative of mestizaje, the china poblana has been rendered symbolically as the nation and, as part of nationalism, has been considered the ideal woman. Mexican poet Amado Nervo’s 1938 poem “Guadalupe La Chinaca," for instance, elevates la china poblana to the status of another iconic Mexican nationalist and gendered figure, La Virgen de Guadalupe (Gillespie 32-34). The poem portrays both la china poblana and La Virgen as chaste, proper women who represent the Mexican nation; in the poem, both figures are recognized for their adornment in the colors of the Mexican flag. Many have also highlighted china poblana dress as emphasizing the wearer's demureness but also sexual availability; for example, travel writers in Mexico in the nineteenth century depicted women who danced the jarabe tapatío in china poblana costumes as faithful to their dancing partners yet sexually available. ${ }^{15}$ The sexualized connotation of the outfit itself, along with the dominant view of peasant women as loose and sexually available, led many during this period to associate women who wore china poblana dress as having loose morals (Earle 73). ${ }^{16}$ European 
travel writers in Mexico during this period also frequently emphasized the lower necklines of the blouses (Randall 57). This style of attire, worn by working women who were visible in the public sphere, contrasted starkly, as Randall explains, "with the more cloistered lives of Mexican elite women for their movements were often limited to a morning walk to mass dressed in traditional Spanish black with mantilla" (45).

Just as female singers of rancheras self-stylize the musical genre to employ feminist interventions, specifically in their performance of gendered lyrics that transpose gender roles, female ranchera singers have employed costume choices, as Nájera-Ramírez explains, to manipulate and expand male/female gendered binaries (192, 200). For example, Rita Vidaurri, a contemporary of Mendoza, alternated between the china poblana and charro outfits worn by women, and she self-stylized them depending on the genre of music and the spaces in which she performed (Vargas, "Rita's Pants" 6-9). As Vargas explains, "[Vidaurri] dressed in long, elegant dresses when she sang boleros and with big orquestas, and wore charro attire when she sang rancheras with her guitar" ("Rita's Pants" 6). As a singer in Mexico in the 1940s, Vidaurri wore full charro attire with pants instead of a skirt, and, as Vargas explains, she "dislodge[d] femininity from the colonial project of a disempowered hetero-masculinity" ("Rita's Pants" 9). ${ }^{17}$ Lucha Reyes, a Mexican mariachi and ranchera singer who was popular on both sides of the border throughout the 1930s and 1940s, wore traditional china poblana costumes in her performances, yet with her low vocal range and singing voice, similar to Mexican singer Chavela Vargas's in the twentieth century, she was “consistently coded as performatively incongruous with gender normative femininity" (Vargas “Rita's Pants" 11). In Reyes's case, her choice of the hyper-feminine china poblana costume combined with her low voice and masculinized public presence queered the hetero-normative attire. Rosita Fernández, who mostly sang canciones 
romanticas and boleros, and who was frequently accompanied by large Mexican orquestas, wore china poblana costumes that looked more like ball gowns and included off-the-shoulder and low necklines; such self-fashioning of the china poblana outfit suggests how she stylized the dress to underscore her femininity (Vargas, "Rosita Fernández” 170; Peña 64).

Mendoza's donning of china poblana attire, as evidenced by publicity photos, advertisement photos, and album covers, indicates a self-stylization that both conformed to the hyper-feminine associations of the costume and deemphasized focus on her female body. Her use of designs and materials in her modifications of the dress focuses the viewer's attention on the elaborate designs of her costumes as powerful spectacles of mexicanidad. Mendoza's unique self-stylizations included her addition of colorful sequin appliqués, embroidery, and ribbons to the top; a fuller petticoat; and use of a variety of colors, including pink and black; later in her career she also sported high heels, a unique characteristic of her self-fashioning of the dress. Mendoza also self-stylized the costume by incorporating elements from other Mexican regional musical traditions, as well as US country music. Photos show Mendoza wearing full blouses, not low-cut ones, that covered her arms, with some images showing her in long-sleeved, high-necked blouses fully covering her chest, more in the style of ballet folklórico costumes. Other photos show her in ruffled, embroidered blouses and full petticoats that share similarities with the costumes of Anglo-American country western singers of the time, such as Kitty Wells.

A unique element of Mendoza's performance aesthetic is her powerful embrace of her twelve-string guitar in a classical guitarist position (figs. 11.2 and 11.3). In most photos she is shown with the guitar raised in front of her body in a playing position, by her side, or in front of her (a traditional pose for US country western female guitarists of the period). When Mendoza held her guitar prominently in front of her body, attention shifted away from her frame, 
deemphasizing her sexuality and redirecting the focus instead on her artistry as a singer and guitar player. The prominent display of her guitar in front of her body or lower torso, as Castro explains, "minimize[s] the gaze on her female body and force[s] it to focus on her guitar and strong expression on her face." In publicity photos, Mendoza also rarely looks directly at the camera (a pose common among Mexican female performers); instead, focusing attention on her guitar. In these photos the instrument is not only an element of her musical artistry but also an integral part of her self-styling. In many images, it appears her guitar flows into her costume and is therefore an essential part of her physical presence and performance persona.

\{FIGS 11.02 and 11.03 about here

$<\mathrm{TXT}>\quad$ Unlike that of other female singers working in the ranchera musical tradition during the early twentieth century, Mendoza's costuming was not only an integral feature of her performance persona but also a crucial aspect of her public appearance. As shown in archival photos, the china poblana costume became a defining feature of her image from about 1938, when she began to wear the costume in all public appearances, until the end of her singing career in the late 1980s. Indeed, it is rare to find any photos of Mendoza taken after 1938-either on the stage or off — not wearing some version of the china poblana costume (see fig. 11.2). From 1938 to the end of her career, images of Mendoza wearing a china poblana costume holding her twelve-string guitar were used as publicity photos, performance advertisements, and music compilation covers.

Even though the china poblana costume became a defining feature of her onstage performances in the Mendoza Family Variety Act in the early and mid-1930s, Mendoza still 
wore everyday clothing in publicity photos. In a photo from October 21,1936 , for her recording for RCA Victor in San Antonio (fig. 11.3) — three years after she had started donning china poblana dress for the Mendoza Family Variety Act-Mendoza wears contemporary clothing, including a long-sleeved, button-down paisley shirt, long black skirt, and short-heeled shoes. Two years later, however, in photo of Mendoza recording in her home in San Antonio (see fig. 11.2), she is shown wearing her characteristic china poblana attire. In describing the 1938 photo, which was taken after she returned from touring in California, Mendoza recalled,

$<\mathrm{EX}>$ When we got back to San Antonio, well, I guess that my name had spread from my recordings, the family show, and, especially, from our highly publicized tour to California, so then the local press began to come to my house to do interviews. I was even interviewed by the San Antonio Light. ... One time, they even took a picture of me and my two little girls. It was probably around 1938. It was a photograph of me seated with my two little girls at my side. (Strachwitz and Nicolopulos 139)

$<$ TXT >In a circa-1940s photo of Mendoza and her two oldest daughters, Yolanda and Lydia, at her San Antonio home she is also wearing china poblana dress, suggesting she consciously chose to wear this attire when the press visited to take photos. Mendoza likely derived great confidence and pleasure from donning the attire for her public appearances: it was the costume by which audiences began to recognize her, and by which she began to recognize herself as a performer. Mendoza's choice to wear china poblana in all public appearances also enabled her to project and construct her performance persona as an embodiment of mexicanidad. As evidenced by the 1938 photo (fig. 11.2) and all photos thereafter, the china poblana costume became the defining 
feature of all of Mendoza's public appearances, including documentaries and photos taken of her at home and in recording sessions. The documentary Chulas Fronteras (directed by Les Blank, 1976), for example, shows Mendoza making tamales with her sisters and other relatives, but she is the only one in traditional Mexican dress. In this sense, the china poblana costume became the frame by which she was constructed as a domesticated woman in the documentary, illustrating the risk that Mendoza took by wearing the costume in all aspects of her life. Even in her senior years, Mendoza wore china poblana and traditional Mexican costumes in photo shoots and public appearances. Even after she suffered a stroke in the 1980s, public photos show her wearing housedresses that she had sewn in the china poblana style. And for an audio interview conducted by Deborah Vargas for the Smithsonian Institute's Latino Music Oral History Project in the 1990s, Mendoza also donned a china poblana dress. ${ }^{18}$

$<$ A $>$ China Poblana as Performance of Mexicanidad in the National Spotlight

$<$ TXT>From the 1960s to the 1980s, Lydia Mendoza's popularity increased as she toured folklife festivals and universities, which propelled her into the national spotlight. She performed at the Smithsonian Festival of American Folklife in Montreal in 1961 and was a guest speaker at universities, including California State University, Fresno, in 1982, where she was interviewed by Professors Gene Bluestein and Manuel Peña. Mendoza also performed at the inauguration of President Jimmy Carter in 1977, and she became one of the first recipients of the National Heritage Fellowship Award from the National Endowment for the Arts in 1982. After she stopped performing, in the late 1980s, she was honored by both mexicano and US national institutions, inducted into the Conjunto Hall of Fame in San Antonio, and awarded the highest 
national honor for artists in the United States, the National Medal of the Arts, from President Bill Clinton at the White House in 1999 (Broyles-González, Lydia Mendoza’s Life xi-xv).

In all these performances, as evidenced by photos and performance footage, Mendoza continued to wear--both on- and offstage--distinctive and elaborately detailed hand-sewn costumes in the china poblana style. Yet, distinct from her earlier costumes, these consistently combined several styles of Mexican dress, including china poblana and ballet folklórico, and unlike earlier color palettes, these costumes were in the traditional color palette, that of the Mexican flag. In one photo from a 1970s performance, for instance, Mendoza wears a red, white, and green china poblana costume with a backdrop of woven Mexican serapes and a stereotypical Mexican sombrero, a costume signaling a generalized Mexican identity common in US popular culture and media. Public photos from the 1970s suggest the ways in which Mendoza's dress came to characterize typical or generalized Mexican dress during this period to non-Latina/o audiences, deploying mexicanidad and risking aligning itself with stereotypical signifiers of Mexican identity and culture, such as the serape and Mexican sombrero, prevalent in US Hollywood film and popular culture.

But during this same period Mendoza also deployed mexicanidad to self-stylize lo mexicano in an innovative way: wearing fuller petticoats and high heels, and sporting black china poblana gowns with elaborately detailed sequin appliqués on her blouses and skirts. She also continued to wear her hair pulled back with colorful ribbons, adding more ribbons and paper flowers. As in photos of her earlier performance years, the later photos of Mendoza wearing these costumes reveal her pride and self-confidence, signaling a politics of claiming Mexican identity to audiences in both the United States and Mexico. Just as Deborah Paredez views Selena Quintanilla's self-fashioning in Tejana music, I suggest that Mendoza's performance 
attire signaled the "bold assertion of a working-class racialized style without apology" (160).

It would be remiss, however, to not consider the function of china poblana costuming for Mexican female performers in the United States as revealing the "demand of authenticity placed on minoritarian communities and, in particular, on racialized female bodies" (Paredez 3). As Mendoza's audience base grew beyond a working-class mexicano audience from the 1960s to the 1980s, her costuming choices risked fulfilling a stereotype for mainstream US audiences desiring a familiar, feminized, and domesticated "other." At the Smithsonian American Folklife Festival in Montreal in the 1960s, Mendoza's performance stood in for and represented "Mexican folk music" among other multicultural forms of folk music; at Jimmy Carter's inauguration, Mendoza represented "authentic" Mexican identity amid other multicultural performers at the event. Donning her self-stylized traditional Mexican dress costumes in these performances, Mendoza offered a stereotype of Mexican female identity prevalent in US popular culture and Hollywood film. Her long career therefore suggests how she carefully negotiated "between [an] exquisitely crafted self-image and an embodiment of authenticity" (Paredez 160).

$<$ A >Mendoza's Legacy: Archives and Representation in Chicana/o Visual Art

$<$ TXT $>$ Today Mendoza's china poblana dresses are held by national museums and university archives, including the Smithsonian Folklore Museum Collection, the Ester Hernández Papers at Stanford University, and the Yolanda Broyles-González Papers at Texas A\&M University. ${ }^{19}$ In 2005 the Smithsonian acquired one of Mendoza's china poblana costumes for its permanent collection (along with Rosita Fernández's and Selena’s costumes); the costume was included in

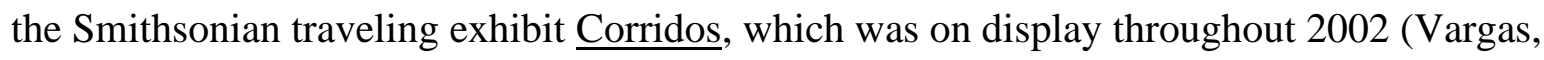


Dissonant Divas 243n93). Her costume was also featured, along with those of other famous Tejana singers, in the exhibit Mexican Treasures of the Smithsonian, which was shown from September 5, 2007, through January 27, 2008. In the context of the Smithsonian, Mendoza's costumes are referred to as "objects" of Mexican culture, signaling the risk of fetishizing her costumes as artifacts of authentic Mexican identity, whereas Mendoza's costumes in the university archives are included within a large body of work and scholarship by Hernández and Broyles-González, who have situated and contextualized Mendoza's voice and perspective in their art and scholarship, respectively.

Mendoza's self-stylizations of the china poblana dress are so central to the memory of the singer that her elaborately sewn dresses and fashion are also included in Chicana public muralism and in visual art, particularly by Chicana artist Ester Hernández. Hernández's visual depictions of Mendoza's performance aesthetics suggest the artist's own deployment of mexicanidad through her focus on the figure. Specifically, she deploys a Chicana feminist framing of Mendoza as a powerful female role model, underscoring Mendoza's "style politics" (Ramírez) and emphasizing how, through her artistry, which was both sonic and visual, Mendoza claimed space and belonging for Mexicanas. Hernández's artistic depictions of the figure claim Mendoza's dress as central to her legacy for Mexicanas and Chicanas. By focusing on individual elements of Mendoza's self-stylizations - her hair, makeup, and high heels—-Hernandez elevates the sites of costume and fashion, arenas traditionally deemed as passive and of gendered femininity, as active and central aspects of Mendoza's legacy as a performer. Throughout the late 1990s, Hernández created many visual art pieces that pay homage to Mendoza, whom she describes as her artistic madrina: 
$<$ EX $>$ Lydia Mendoza is one of my favorite people in the world. I consider her my madrina, my godmother. There were times in my life when I didn't know what I was doing and I was really struggling. I was at a real turning point when I met her. She gave me advice about how hard life is, but if you find something you really want, then do it." (qtd. in Harlan) $)^{20}$

$<$ TXT>In this way, Hernández fashioned Mendoza as a powerful role model for Chicanas. Her 1998 serigraph Con Cariño Lydia Mendoza (with affection) (fig. 11.4), for example, depicts Mendoza as a feminist icon of mexicanidad by including pre-Columbian imagery that deconstructs binary gender roles. The serigraph recontextualizes a popular photo of Mendoza wearing a china poblana costume in the Mexican color palette of red, white, and green while resting her guitar in front of her. Hernández's rendering of this classic photo includes a background element that fuses Indigenous and Mexican imagery: the medallion behind Mendoza simultaneously invokes the syncretic form of the pre-Columbian Coyolxauhqui, as well as the Aztec symbology of an eagle eating a serpent. Many of Mendoza's china poblana outfits often included sequined images of the eagle and serpent, particularly on the flowing black capes she wore later in her career (Broyles-González, Lydia Mendoza's Life 187). For Chicana artists, Coyolxauhqui represents "not only an incredibly violent dismembering of a warrior woman but also the need to re-member and heal not only ourselves but also our histories and cultures from this violent and misogynistic past.... [W]e have a long history of goddess warriors to guide and protect us" (A. López 272). By invoking Coyolxauhqui through the image of the eagle, Hernández uses Chicana feminist reconfigurations of Aztec symbology to portray Mendoza as a powerful feminist icon. 
\{FIG 11.04 about here $\}$

$<$ TXT $>\quad$ Many Chicana/o artists have also depicted Mendoza in public murals in Latina/o neighborhoods and art centers in Texas. While these murals signal the role of art in educating the community about Mendoza's life and career, they also — by spotlighting her costuming — show Mendoza's physical presence and self-stylizations as part of her claiming of public space. Broyles-González's view of Mendoza’s deployment of mexicanidad in her dress throughout her performance career is useful here: "Her body, a billboard of Mexicanness, bravely flaunted those boldly sequined, flowered, brightly colored dresses even through historical periods in which public displays of Mexicanness targeted you for governmental harassment and/or deportation" (Lydia Mendoza's Life 187-188). Mendoza is featured in Judy Baca's mural Danza de la Tierra (2009), commissioned by the Dallas Latino Cultural Center, which graces the lobby of the cultural center's performance hall; the mural focuses on two dancers in motion, with the female dancer wearing a colorful folkloric skirt featuring iconic Latino performers and artists, including Mendoza. ${ }^{21}$ Theresa A. Ybáñez also depicts Mendoza's image in the mural Corazones de la Comunidad (1999), along with three other female heroes of San Antonio, as part of her mural series Mujeres de San Antonio, which covers the walls of buildings on San Antonio's South Side. The mural La Música de San Anto (2009), in San Antonio’s Westside, was coordinated by the San Anto Cultural Arts Community Mural Program and painted by lead artist David Blancas. It features Mendoza among other images of female Tejana singers and performers from the 1930s and 1940s, including Rosita Fernández and Eva Garza. Blancas comments that "these women were huge and I think it's essential that we center these women here because we knew 
they never played at most of the venues the other artists played in, so we want to be able to create their own space within the mural since they were so significant and continue to be so" (qtd. in Romero 4). Mendoza's powerful physical and artistic presence on these public murals, in depictions that emphasize here beautiful and elaborate china poblana costumes, function as sites of mexicanidad that necessarily claim space and belonging for various Mexicana/o communities in the United States.

In published interviews, Mendoza did not explicitly comment on her costume as a crucial aspect of her public persona, but her contemporary Rosita Fernández did: "Para nosostros [mujeres] era el vestuario. Quiero decir la mitad de tu actuación / For us [women] it was the costume. What I meant to say is that, it was half of the performance" (qtd. in Vargas, "Rosita Fernández"179). As this chapter illustrates, Mendoza's self-stylizations of the china poblana costume were not only half of the performance, but an integral and powerful aspect of her unique working-class aesthetic that, like her music, appealed to mexicano audiences in both the United States and Mexico.

$<\mathrm{A}>$ Works Cited

<BIB>Aviña, Rafael. David Silva: Un Campeón de Mil Rostros. Universidad Nacional Autónoma de México, 2007.

Broyles-González, Yolanda. El Teatro Campesino: Theater in the Chicano Movement. U of Texas P, 1994.

------. Lydia Mendoza's Life in Music / La Historia de Lydia Mendoza. Oxford UP, 2001.

-----. "Ranchera Music(s) and the Legendary Lydia Mendoza: Performing Social Location and 
Relations." Chicana/o Cultural Studies Reader, edited by Angie Chabram-Dernersesian, Routledge, 2006, pp. 352-360.

Castro, Kelley Merriam. “Partial Deaths, Femininity, and (ahem) Mendozidad?.” Blog post, Folklore Studies, Ideology, and Authenticity, 22 Nov. 2011.

García, Juan Ramon. Operation Wetback: The Mass Deportation of Mexican Undocumented Workers in 1954. Greenwood, 1980.

Gillespie, Jeanne L. “Gender, Ethnicity, and Piety: The Case of the China Poblana." Imagination Beyond Nation: Latin American Popular Culture, edited by Eva P. Bueno and Terry Caesar, U of Pittsburgh P, 1998, pp. 19-40.

Gutiérrez, Laura G. Performing Mexicanidad: Vendidas y Cabareteras on the Transnational Stage. U of Texas P, 2010.

Harlan, Teresa. “A Conversation with Ester Hernández.” The Art of Provocation: Ester Hernández, C. N. Gorman Museum, 1995.

Hayes, Joy Elizabeth. "National Imaginings on the Air: Radio in Mexico, 1920-1950." The Eagle and the Virgin: Nation and Cultural Revolutions in Mexico, 1920-1940, edited by Mary Kay Vaughan and Stephen E. Lewis, Duke UP, 2006, pp. 243-258.

Hershfield, Joanne. Imagining La Chica Moderna: Women, Nation, and Visual Culture in Mexico, 1917-1936. Duke UP, 2008.

Hurtado, Aída. The Color of Privilege: Three Blasphemies of Race and Feminism. U of Michigan P, 1996.

López, Alma. "It's Not about the Santa in My $\underline{\text { Fe, }}$ but the Santa Fe in My $\underline{\text { Santa.. }}$ Our Lady of Controversy: Alma López’s Irreverent Apparition, edited by Alicia Gaspar de Alba and Alma López, U of Texas P, 2011, pp. 249-292. 
López, Rick A. Crafting Mexico: Intellectuals, Artisans, and the State after the Revolution. Duke UP, 2010.

Nájera-Ramírez, Olga. "Unruly Passions: Poetics, Performance, and Gender in the Ranchera Song.” Chicana Feminism: A Critical Reader, edited by Gabriela F. Arredondo, Aída Hurtado, Norma Klahn, Olga Nájera-Ramírez, and Patricia Zavella, Duke UP, 2003, pp. 184-210.

Paredez, Deborah. Selenidad: Selena, Latinos, and the Performance of Memory. Duke UP, 2009. Peña, Manuel. Música Tejana: The Cultural Economic of Artistic Transformation. Texas A\&M UP, 1999.

Pérez-Torres, Rafael. Mestizaje: Critical Uses of Race in Chicano Culture. U of Minnesota P, 2005.

Ramírez, Catherine. The Woman in the Zoot Suit: Gender, Nationalism, and the Cultural Politics of Memory. Duke UP, 2009.

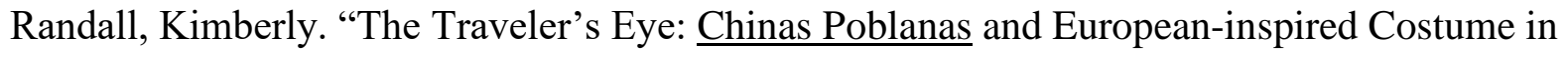
Postcolonial Mexico.” Latin American Fashion Reader, edited by Regina A. Root, Berg, 2005, pp. 44-65.

Romero, Cynthia. "Mural to Honor Notable Musicians: Blancas Takes Lead on Artwork." Conexión, 24 July 2008, p. 4.

Saldaña-Portillo, Josefina. Who’s the Indian in Aztlán? Re-Writing Mestizaje, Indianism, and Chicanismo from the Lacandón. Duke UP, 2001.

Strachwitz, Chris, and James Nicolopulos, editors. Lydia Mendoza: A Family Autobiography. Arte Público, 1993.

Vargas, Deborah R. Dissonant Divas in Chicana Music: The Limits of La Onda. U of Minnesota 
P, 2012.

------ "Rita's Pants: The Charro-Traje and Trans-Sensuality.” Women \& Performance: A Journal of Feminist Theory, vol. 20, no. 1, 2010, pp. 3-14.

------. “Rosita Fernández: La Rosa de San Antonio.” Gender on the Borderlands: The Frontiers

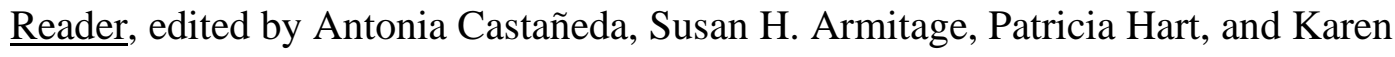
Weathermon, U of Nebraska P, 2007. Velázquez, Marco, and Mary Kay Vaughan. "Mestizaje and Musical Nationalism in Mexico.” The Eagle and the Virgin: Nation and Cultural Revolutions in Mexico, 1920-1940, edited by Mary Kay Vaughan and Stephen E. Lewis, Duke UP, 2006, pp. 95-118.

\footnotetext{
${ }^{1}$ When Mendoza's mother, Leonor, passed away in 1954, the family variety act disbanded, and Mendoza began to perform consistently as a solo artist from 1954 to the end of her career in the 1980s.

${ }^{2}$ The colors of the Mexican flag and the eagle imagery, which are now associated with la china poblana, first developed in a 1910 centennial celebration when Spanish performer Maria Conesa wore a skirt with an eagle on it for President Porfirio Díaz (Velázquez and Vaughan 99).

${ }^{3}$ The term china poblana also refers to an Indian (South Asian) slave named Mirra who was kidnapped and christened Catarina de San Juan, and who lived in Puebla, Mexico; the term china meant "slave" or "servant" in seventeenth-century Mexico (Gillespie).

${ }^{4}$ As Pérez-Torres explains, "Mestizaje implies a doubleness experienced through the mixed-race bodies of the mestiza and mestizo, one in which a sense of belonging coexists within an awareness of exclusion" (12).

${ }^{5}$ As Rick López explains,
}

$<\mathrm{EXB}>$ Before the china poblana and tehuana vogue reached new heights in the 1920s, they already were ubiquitous in festivals, revue theater, film, and public cultural events. Mexico's elite also adopted these outfits to celebrate national holidays, and by 1921 these styles had become so generalized that even members of the United States diplomatic and business colony, with a reputation for being insulated from Mexican culture, donned china poblana outfits for their celebrations of the Fourth of July. There was nothing particularly novel or revolutionary about the china poblana and the tehuana, which largely had been emptied of racial and social class implications. (36)

${ }^{6}$ Images of Mendoza self-styling the china poblana outfit can be found in the Lydia Mendoza Collection of the Houston Area Digital Archives. This extensive online digital photo archive of Mendoza is held by the Houston Metropolitan Research Center of the Houston Public Library and includes publicity stills, photos of her public performances, and photos of recording sessions 
at her home and in the studio. See digital.houstonlibrary.org/cdm/search/collection/images/searchterm/mss0123/order/nosort/. ${ }^{7}$ Deborah Vargas makes a similar argument about Rosita Fernández in Dissonant Divas (39).

${ }^{8}$ The charros orginated in the haciendas of eighteenth-century Mexico, serving as part of private militias known for equestrian skills and expert marksmanship that protected ranch estates. In post-revolutionary Mexico, the charro emerged as a symbol of Mexican nationalism, particularly as a masculine symbol of home, family, and nation (Nájera-Ramírez; Vargas, "Rita's Pants"). By the 1930s, the charro costume had become linked with mariachi music because the Mexican government required mariachi musicians to wear the outfits (Nájera-Ramírez 7). Today the charro is still most often associated with mariachi music and continues to be a powerful symbol of Mexican nationalism and stereotyped masculinity. As Nájera-Ramírez explains, "Ideals of patriotism (nation) and manhood (gender) become fused together so that the charro continues to be a powerful symbol through which to foster a sense of Mexicanness even, perhaps especially, for those mexicanos living in the U.S." (11). While men mostly sport charro costumes in the ranchera genre, some woman, notably Rita Vidaurri, wear charro pants, which Vargas argues produces a "trans-sensuality of mexicanidad" that "initiates differently configured constructions of femininity - ranging from effemininity to counter-hegemonic femininity - that will not allow its reduction simply to a place of disempowerment" (9).

${ }^{9}$ The bracero program was a contract labor agreement intended to bring Mexican laborers to the United States as temporary legal migrants who would not adversely affect the wages and working conditions of domestic farm workers. Instead the program led to an influx of thousands of undocumented Mexican migrants who began to work and live in the United States; many of them entered without documentation because only one out of ten applicants ever received a contract under the bracero program. Racial discrimination directed at this new wave of Mexican immigrants led to Operation Wetback, a series of Border Patrol operations that swept across the agricultural regions of the Southwest. These threats of mass deportation were intended to pressure undocumented Mexican immigrants to leave voluntarily, but led to the direct deportation of Mexican immigrants and US citizens of Mexican descent (García 169-182). ${ }^{10}$ From 1941 to 1947, Mendoza and her sister María would sing and appear occasionally around San Antonio at fiestas or other special family and political events (Strachwitz and Nicolopulos 147).

${ }^{11}$ Mendoza and her family found it very difficult at first to get invitations to perform at Angloowned theaters due to racial segregation. Even those theaters that were owned by Anglos but catered to mexicano audiences did not invite her at first because they had not heard of Lydia Mendoza's music. After they performed at the Colon Theater in El Paso, Texas, in 1936 to soldout houses, the owner of the theater, Mr. Calderon, phoned other theater owners, including Anglo Americans, who operated theaters across the US Southwest, on Mendoza and her family's behalf. This phone call led to the Mendoza family receiving invitations to perform, and Mendoza noted that her family's 1937 performance at the Mason Theater in Los Angeles was an extremely successful sold-out show (Strachwitz and Nicolopulos 131-133).

${ }^{12}$ La china poblana was popular in many state-sponsored Mexican films, including Redes (directed by F. Zinnemann and E. Gomez Muriel, 1934) and Vámonos con Pancho Villa (directed by F. de Fuentes 1935) (Randall 133). Mexican films of the 1920s that preceded the comedias rancheras--such as El Caporal, En la Hacienda, and La Raza Azteca--also included Mexican actresses wearing china poblana costumes in idealized hacienda contexts. La china poblana also appeared in La historieta de Aventuras Rancheras (comic book serials that idealized 
life on the Mexican hacienda), including Los Bandidos de Río Frío, Los Plateados, Los Charros del Bajío and Juan Gallardo (Hershfield 132).

${ }^{13}$ María Luisa Zea was so well known for her performance in the film that she was referred to as La India Bonita throughout her career (Aviña 24).

${ }^{14}$ Both Broyles-González (El Teatro Campesino) and Aída Hurtado describe how Chicanas in El Teatro Campesino during the 1960s and 1970s confronted the sexist view of female performers in the public sphere as transgressing normative femininity. As Hurtado explains, "Even though participation in El Teatro was to bring political consciousness to Chicano communities, many of the women actors were criticized in their families for what they perceived as inappropriate behavior for women" (81).

${ }^{15}$ German-born Mexican photographer Hugo Brehme's photographs of Mexican women and men dancing the jarabe tapatío while wearing china poblana and charro costumes exemplify this characteristic of the china poblana as loyal yet sexually available (Hershfield 136).

${ }^{16}$ Lithographs of women donning la china poblana attire from 1836, for instance, frequently show them smoking and talking unchaperoned (Gillespie 31). Fanny Calderon de la Barca, the wife of a Spanish minister, wanted to wear the china poblana while on a visit to Mexico during this period, but was discouraged to do so because china poblanas were considered "unsavory women" (Gillespie 31-32); this point highlights the loose moral character associated with the figure.

${ }^{17}$ Vidaurri explains that she felt more freedom to break gendered fashion binaries in Mexico:

$<$ EXB $>$ I was the only women to wear pants. . . I liked them. I could never do that here [in Texas] but I loved wearing them and I became known for that. At that time in Mexico, las mujeres no usban pantalones [the women didn't wear pants]. I used to come out with real high heels and my tight black charro pants [and they yelled] "Esa. Jorge Negreta!" I wanted to wear pants like a charro. (qtd. in Vargas, "Rita's Pants" 10).

${ }^{18}$ Lydia Mendoza, interview with Deborah Vargas, 15 July 2000, Smithsonian Latino Music Oral History Project.

${ }^{19}$ Mendoza's costumes have also been acquired by academic archives, specifically as part of Chicana artist Ester Hernández's papers (costumes that Mendoza donated to Hernández) in the Special Collections and University Archives at Stanford University, and in Chicana scholar Yolanda Broyles-González's papers at the Cushing Library Special Collections at Texas A\&M University (which holds two costumes donated by Mendoza to Broyles-González).

${ }^{20}$ Hernández's visual representations of Mendoza include: Con Cariño, Lydia Mendoza (1987); Con Cariño Lydia Mendoza (With affection . . . ) (1998 and 1999), produced as both a serigraph and graphite drawing; Lydia Mendoza, La Reina Tejana (Lydia Mendoza, Texas Queen) (1987 and 2005), both a pastel portrait and acrylic on canvas; Portrait of Lydia Mendoza 1983 (1999); Portrait of Lydia Mendoza 1985 (n.d.); Los Tacónes de Lydia Mendoza (Lydia Mendoza's high heels) (1999), a pastel portrait; and other works. This work was part of the Cantos del Pueblo: Tejano Musical Landscapes (2007) exhibit at the Museo Alameda in San Antonio and the Sounds Latino exhibition (2008) at the University of California, Santa Barbara.

${ }^{21}$ Judy Baca produced the mural in the UCLA Social Art and Public Art Resource Center (SPARC) Cesar Chávez Digital Mural Lab. 